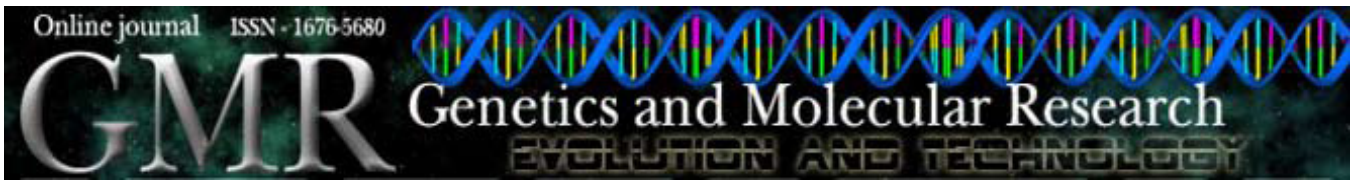

\title{
Phylogenetic relationships of Malayan gaur with other species of the genus Bos based on cytochrome $b$ gene DNA sequences
}

\author{
M.K.A. Rosli' ${ }^{1}$, S.S. Zakaria ${ }^{1}$, S.M.F. Syed-Shabthar ${ }^{1}$, Z.Z. Zainal ${ }^{2}$, \\ M.N. Shukor ${ }^{1}$, M.C. Mahani ${ }^{1}$, O. Abas-Mazni ${ }^{3}$ and B.M. Md-Zain ${ }^{1}$ \\ ${ }^{1}$ School of Environmental and Natural Resource Sciences, \\ Faculty of Science and Technology, Universiti Kebangsaan Malaysia, \\ Selangor, Malaysia \\ ${ }^{2}$ Department of Wildlife and National Parks (PERHILITAN), \\ Peninsular Malaysia, Kuala Lumpur, Malaysia \\ ${ }^{3}$ Agro-Biotechnology Institute, Malaysia (ABI), Serdang, Selangor, Malaysia \\ Corresponding author: B.M. Md-Zain \\ E-mail: abgbadd@ukm.my / abgbadd1966@yahoo.com
}

Genet. Mol. Res. 10 (1): 482-493 (2011)

Received August 5, 2010

Accepted January 6, 2011

Published March 22, 2011

DOI 10.4238/vol10-1gmr1002

\begin{abstract}
The Malayan gaur (Bos gaurus hubbacki) is one of the three subspecies of gaurs that can be found in Malaysia. We examined the phylogenetic relationships of this subspecies with other species of the genus Bos (B. javanicus, B. indicus, B. taurus, and B. grunniens). The sequence of a key gene, cytochrome $b$, was compared among 20 Bos species and the bongo antelope, used as an outgroup. Phylogenetic reconstruction was employed using neighbor joining and maximum parsimony in PAUP and Bayesian inference in MrBayes 3.1. All tree topologies indicated that the Malayan gaur is in its own monophyletic clade, distinct from other species of the genus Bos. We also found significant branching differences in the tree topologies between wild and domestic cattle.
\end{abstract}

Key words: Malayan gaur; Bos gaurus hubbacki; Phylogenetics; Wild cattle; Cytochrome $b$ gene 


\section{INTRODUCTION}

The genus Bos consists of six extant species; B. gaurus (gaur), B. javanicus (banteng), $B$. frontalis (gayal), B. indicus (zebu cattle), B. taurus (taurine cattle), and B. grunniens (yak) (Wilson and Reeder, 2005). In Asia, the gaur is the second largest terrestrial mammal after the elephant. Three subspecies of gaurs are generally recognized: B. g. gaurus found in India, Southern Nepal and Bhutan, B. g. laosiensis distributed in Myanmar, Laos, Vietnam, and Cambodia and B. g. hubbacki, which exists only in Peninsular Malaysia and Southern Thailand (Duckworth et al., 2008). Gaurs live in the wild and face an increasing threat of extinction. In the very recent past, gaurs have been significantly reduced in numbers (Nguyen, 2009). Globally, B. gaurus is currently classified as vulnerable by the International Union for the Conservation of Nature (IUCN) Red List. There are an estimated 13,000 to 30,000 wild gaurs globally, with the population of mature individuals estimated to be between 5200 and 18,000 (Nguyen et al., 2007).

The Malayan gaur (B. g. hubbacki), locally known as seladang, is the only remaining wild cattle species in Peninsular Malaysia. Malayan gaurs can be found in several states, including Pahang, Kelantan, Kedah, Perak, and Terangganu (Yusof, 1981). According to Sahir (2001), there are about 500 remaining individuals in Malaysia. Wild populations of gaur have declined significantly in this country (Conry, 1989). It has been declared as a "Totally Protected" animal under the Wildlife Protection Act 76/72, Schedule I (wild animals) by the Malaysian government. Since 1982, in-situ conservation efforts for the Malayan gaur by the Department of Wildlife and National Parks (DWNP) have included steps to prevent its extinction in response to the growing concern that survival in the wild may be threatened by severe habitat reduction (Sahir, 2001). Malayan gaurs share many morphological characteristics with the other two subspecies. According to Groves (2003), there are multivariate overlaps in the analysis of skull and horn measurements between Indian and Southeast Asian subspecies. Southeast Asian subspecies are much bigger, with relatively shorter nasal bones, a narrower occiput and a narrower horn span. Compared to the Indian gaur, the ascending branch of the premaxilla of the Southeast Asian subspecies generally does not reach the nasal area, as it does in the Indian subspecies (Duckworth et al., 2008). Some of the shared characteristics of gaurs include being sexually dimorphic, a muscular-like bump on the male shoulder with less muscles formed on females, white stockings, gray-brown hair on the forehead and between their horns, average body size of about 2.5 to $4 \mathrm{~m}$ and a weight of around 700 to $1500 \mathrm{~kg}$ (Medway, 1983).

Phylogenetically, gaurs belong to the tribe Bovini and are further assigned to the subtribe Bovina, which includes some other extant species such as B. taurus (taurine cattle), B. indicus (zebu cattle), B. javanicus (banteng), B. grunniens (yak), Bison bison (American bison), Bison bonasus (European bison), and other Bubalus species (Hassanin and Ropiquet, 2004; Hassanin et al., 2006). To date, studies on the relationship of species in the genus Bos have been investigated by researchers around the world using several types of molecular data and techniques: a) mitochondrial DNA (mtDNA) sequence data (Matthee and Davis, 2001; Cai et al., 2007; Gu et al., 2007; Ginja et al., 2010); b) nuclear DNA sequence data and microsatellites (Kikkawa et al., 2003; MacEachern et al., 2009), and c) DNA fingerprinting and amplified fragment length polymorphism (AFLP) techniques (Vasil'ev et al., 2002; Buntjer et al., 2002).

Mitochondrial genome has been extensively used to amplify many genes of interest for phylogenetic studies (Md-Zain et al., 2008, 2010a,b; Lim et al., 2010). The cytochrome $b$ (Cyt $b$ ) gene, in particular, has been used in the investigation of systematic relationships among mammals and is suitable for bovid species. This is due to the higher variation of the Cyt $b$ gene as compared to 
that of other functional areas, the fact that it is detected easily and the availability of high-definition phylogenetic information, especially for species level classification (Irwin et al., 1991). In the Bovinae tribe, Cyt $b$ has been used for the determination of phylogenetic relationships of gayal (Ma et al., 2007), investigation of the taxonomic status of kouprey (Hassanin and Ropiquet, 2004), in the study of species identification, molecular sexing and genotyping of gaur and banteng (Rivière-Dobigny et al., 2009) and related species (Verkaar et al., 2004). However, only few studies have used molecular techniques on the Malaysian subspecies of gaur (Brennan, 1995). We investigated the systematic relationships of Malayan gaur with other species of the genus Bos, based on maternal lineage.

\section{MATERIAL AND METHODS}

\section{Samples and DNA isolation}

Four blood and three tissue samples were collected from seven Malayan gaurs at Jenderak Selatan Wildlife Conservation Centre, Pahang. Blood samples were also collected from Bali cattle of Palong FELDA Farm, Negeri Sembilan, Kedah-Kelantan cattle from Sepang, Selangor and Mafriwal cattle, Friesian cattle and Limousin cattle breed, respectively, from Jerantut Farm (National Institute of Veterinary Biodiversity), Pahang (Table 1). The blood samples were collected and taken back to the lab on ice. Tissue samples were stored in $95 \%$ ethanol. Total genomic DNA was extracted by using the standard extraction kit and protocol provided by QIAGEN DNeasy Blood and Tissue Kit (Simonelli et al., 2009).

\begin{tabular}{llll}
\multicolumn{2}{l}{ Table 1. Details of the Bos species samples. } \\
\hline No. & Sample name & Species & Breed/Locality \\
\hline 1 & Friesian & Bos indicus & Friesian (Jerantut, Pahang) \\
2 & KK 4 & Bos indicus & Kedah-Kelantan (Sepang, Selangor) \\
3 & Limousin & Bos taurus & Limousin (Jerantut, Pahang) \\
4 & Mafriwal & Bos taurus & Mafriwal (Jerantut, Pahang) \\
5 & Gaur 1 & Bos gaurus hubbacki & Malayan gaur (Jenderak, Pahang) \\
6 & Gaur 2 & Bos gaurus hubbacki & Malayan gaur (Jenderak, Pahang) \\
7 & Gaur 3 & Bos gaurus hubbacki & Malayan gaur (Jenderak, Pahang) \\
8 & Gaur 4 & Bos gaurus hubbacki & Malayan gaur (Jenderak, Pahang) \\
9 & Gaur 5 & Bos gaurus hubbacki & Malayan gaur (Jenderak, Pahang) \\
10 & Gaur 6 & Bos gaurus hubbacki & Malayan gaur (Jenderak, Pahang) \\
11 & Gaur 7 & Bos gaurus hubbacki & Malayan gaur (Jenderak, Pahang) \\
12 & Bali & - & Bali cattle (FELDA Palong, Negeri Sembilan) \\
13 & Bali C & Bali cattle (FELDA Palong, Negeri Sembilan) \\
\hline
\end{tabular}

\section{DNA amplification}

Polymerase chain reaction (PCR) was performed using a $25 \mu \mathrm{L}$ reaction mixture containing $1 \mu \mathrm{L}$ genomic DNA, $2.5 \mu \mathrm{L}$ PCR buffer 10X, $1 \mu \mathrm{L} 50 \mathrm{mM} \mathrm{MgCl}_{2}, 0.5 \mu \mathrm{L} 10 \mathrm{mM}$ dNTP mix, $1.5 \mu \mathrm{L}$ each of $10 \mathrm{pmol} / \mu \mathrm{L}$ primer and four units Taq DNA Polymerase in PTC-100 Thermal Cycler (MJ Research Inc.). The complete Cyt $b$ gene fragment of approximately $1140 \mathrm{bp}$ was amplified using mammal universal forward primer L14724B (5'-CGAAGCTTGATATGAAAAACCATCGTTG-3') and reverse primer H15915R (5'-GGAATTCATCTCTCCCGGTTTACAAGAC-3') (Irwin et al., 1991). PCR conditions were as follows; 4 min denaturation at $94^{\circ} \mathrm{C}$, followed by 30 cycles of $30 \mathrm{~s}$ at $94^{\circ} \mathrm{C}$, $30 \mathrm{~s}$ at $56^{\circ} \mathrm{C}, 1 \mathrm{~min}$ at $72^{\circ} \mathrm{C}$, and a final $7 \mathrm{~min}$ extension at $72^{\circ} \mathrm{C}$, before cooling to $4{ }^{\circ} \mathrm{C}$ for $10 \mathrm{~min}$. DNA from PCR products was purified using Vivantis G-F1 PCR Clean-up Kit and was directly sent to the sequencing service company, First Base Sdn. Bhd., to be sequenced. 


\section{Phylogenetic analysis}

Sequencing results were exported as FASTA sequence files. The Cyt $b$ gene sequences of the 13 samples were aligned using the ClustalW multiple alignment algorithm of BioEdit, together with other genus Bos sequences of banteng, zebu cattle, taurine cattle, and yak that were available in GenBank. Additionally, bongo antelope (AF036276) was employed as an outgroup. The sequences used as analysis background and species control from the GenBank can be seen in Table 2. All sequences were analyzed using PAUP 4.0b10 and MrBayes 3.1 for phylogeny reconstruction. Two methods of analysis in PAUP included: 1) neighbor-joining (NJ) with Kimura's 2-parameter (Pevsner, 2009), which takes into account the unequal rates of evolution of transition and transversion, but assumes an equal distribution of nucleotide composition, and 2) maximum parsimony (MP) with 1000 stepwise addition replicates in a heuristic search (Swofford, 2002) and 50\% majority rule consensus. In maximum parsimony, gaps were treated as missing data, with equal weighting for transitions and transversions, and a heuristic search was made with the TBR branch-swapping algorithm. All trees were subjected to bootstrap analysis with 1000 replicates to obtain bootstrap value support. Modeltest 3.7 (Posada and Crandall, 1998) was used to choose the substitution model that best fit the data using the AIC criterion. The best suggested model was subsequently used for Bayesian analysis in MrBayes 3.1.

Table 2. DNA sequences obtained from GenBank.
\begin{tabular}{lllll} 
No. & Sample name & Species & Breed/Locality & GenBank accession No. \\
\hline 1 & Indicus & Bos indicus & New Zealand & AF419237 \\
2 & Taurus & Bos taurus & Angus-X & AY676866 \\
3 & Banteng 1 & Bos javanicus & Banteng & D34636 \\
4 & Banteng 2 & Bos javanicus & Banteng (Indonesia) & D82889 \\
5 & Yak 1 & Bos grunniens & Domestic yak & EU807952 \\
6 & Yak 2 & Bos grunniens & Domestic yak (Bhutan) & AB542192 \\
7 & Yak 3 & Bos grunniens & Bongo antelope & AY374124 \\
8 & Bongo & Tragelaphus eurycerus & AF036276 \\
\hline
\end{tabular}

\section{RESULTS}

DNA from the 13 cattle samples was extracted, amplified and sequenced. Sequences of $1140 \mathrm{bp}$ of Cyt $b$ gene were aligned with other Bos sequences cited from GenBank for analysis purposes. Prior to sequence analysis, the Basic Local Alignment Search Tool (BLAST) was used to compare the nucleotide to sequence databases and calculate the statistical significance of matches. All DNA sequences matched the genus Bos DNA sequences in the online database.

\section{Sequence polymorphism}

From the 21 aligned DNA sequences, a 928-bp portion of the Cyt $b$ gene was extracted and used for further analysis: 190 variable sites were detected, among which 67 variable characters were parsimony-uninformative and 123 characters were parsimony-informative. This finding of only $13.25 \%$ informative sites suggested that Cyt $b$ gene is a very conserved gene in the mtDNA. Investigation on Cyt $b$ of 20 Bos sequences indicated that mutations occur consistently in every 100-bp frame with almost similar rates for parsimony-informative variable characters (Table 3 ). The sequences have an average of 46 transition and 5 transversion pairs with the ratio between pairs being 9.2. 
M.K.A. Rosli et al.

\begin{tabular}{|c|c|c|c|c|c|c|c|}
\hline Sequence & $\begin{array}{r}11222344 \\
3425147326 \\
\end{array}$ & $\begin{array}{r}11111 \\
4555900233 \\
8247305602 \\
\end{array}$ & $\begin{array}{l}1111122222 \\
5667900133 \\
0584817915 \\
\end{array}$ & $\begin{array}{l}2222222222 \\
4455778999 \\
0358365124 \\
\end{array}$ & $\begin{array}{l}3333333333 \\
0122556679 \\
6547176990 \\
\end{array}$ & $\begin{array}{l}4444444444 \\
2223456677 \\
0392462517 \\
\end{array}$ & $\begin{array}{l}44 \\
89 \\
62 \\
\end{array}$ \\
\hline Indicus & ATTAAGTTGA & ССАССТСТАС & GCCCGTCGAT & TTTTTCCGCC & СССССАССТС & ACCACTACTT & $\mathrm{TT}$ \\
\hline Friesian & $\ldots \ldots \ldots$ & $\ldots \ldots \ldots$ & $\ldots \ldots \ldots$ & $\ldots \ldots \ldots$ & $\ldots \ldots \ldots$ & $\ldots \ldots \ldots$ & . \\
\hline KK 4 & $\ldots \ldots \ldots$ & $\ldots \ldots \ldots$ & $\ldots \ldots \ldots$ & $\ldots \ldots \ldots$ & $\ldots \ldots \ldots$ & $\ldots \ldots$ & . \\
\hline Taurus & $\ldots$. & $\ldots \ldots \ldots$ & $\ldots \ldots \ldots$ & . С...... & $. \mathrm{TT} \ldots . .$. & $\ldots \ldots \ldots$ & . \\
\hline Limousin & $\ldots \ldots$ А... & $\ldots \ldots \ldots$ & $\ldots \ldots \ldots$ & . С...... &. T..... & $\ldots \ldots \ldots$ & . \\
\hline Mafriwal & $\ldots$..... & $\ldots \ldots \ldots$ &.$A \ldots \ldots$ & . С...... &.$T \ldots \ldots$ & $\ldots \ldots \ldots$ & . \\
\hline Gaur 1 & $. \mathrm{CC} \ldots \mathrm{ACC} . \mathrm{G}$ & . Т.... . & AT.T.T.. & . ССССТTТАТ & T.TGTG.TC. & .T.T.TCC & . C \\
\hline Gaur 2 & $. \mathrm{CC} . \mathrm{ACC} \cdot \mathrm{G}$ & .Т.... . & AT.T.T.C & . ССССТTТАТ & T.TGTG.TC. & .T.T. . TCC & . C \\
\hline Gaur 3 &. $\mathrm{CC} \ldots \mathrm{ACC} \cdot \mathrm{G}$ & . Т.... . & AT.T.T.C & . ССССТTТАТ & T.TGTG.TC. & .T.T. . TCC & . C \\
\hline Gaur 4 & $. \mathrm{CC} \ldots \mathrm{ACC} . \mathrm{G}$ & .Т.... . & AT.T.T..C & .ССССТTТАТ & T.TGTG.TC. & .т.т. . TCC & . C \\
\hline Gaur 5 & . CC . ACC.G & .T... . . & AT.T.T.C & .ССССТTТАТ & T.TGTG.TC. & .т.T. . TCC & . C \\
\hline Gaur 6 &. $\mathrm{CC} \ldots \mathrm{ACC} \cdot \mathrm{G}$ & .T.... . & AT.T.T.C & .ССССТTTAT & T.TGTG.TC. & .т.т.тतC & . C \\
\hline Gaur 7 & $. \mathrm{CC} \ldots \mathrm{ACC} . \mathrm{G}$ & . T.... . & AT.T.T..C & . ССССтTтАТ & T.TGTG.TC. & .T.T. . TCC & . C \\
\hline Banteng 1 & GCCG.A.C.G & ATGTTC.C.T & .TT...T. & СССССТ.А.Т & . TA. .TTC. & ..T.T.GT.C & . C \\
\hline Banteng 2 & GCCG.A.C.G & ATGTTC.C.T & .TT_..T. & СССССТ.А.Т & . TA. TTC. & .T.T.GT.C & . C \\
\hline Bali 1 & GCCG.A.C.G & ATGTTC.C.T & .TT_..T.C & СССССТ.А.Т & . TA..TTC. & .T.T.GT.C & . C \\
\hline Bali 2 & GCCG.A.C.G & ATGTTC.C.T & .TT_.... & СССССТ.А.Т & .TA..TTC. & .T.T.GT.C & . C \\
\hline Yak 1 & $\ldots . \mathrm{GACCAG}$ & AT .... TCG. &. $\mathrm{T} \ldots \mathrm{AC} \ldots \mathrm{GC}$ & . CCC.T.A.T & ...ATG.TC & GTTG.C...C & C. \\
\hline Yak 3 & $\ldots . \mathrm{GACCAG}$ & AT.... TCG. & .T.TAC.AGC & . С...TTA.T & T.ATG.TCT & GTTG.C...C & C. \\
\hline Yak 2 & ....GACCAG & AT.... TCG. & .T.TAC.AGC & . ССС.ТТА.Т & T.ATG.TCT & GTTG.C...C & C. \\
\hline Sequence & 4455555556 & 6666666666 & 6666666777 & 7777777788 & 8888888888 & 8888999999 & 9 \\
\hline & 9902567891 & 1223345556 & 6778999001 & 2234577800 & 0133333445 & 5579011111 & 2 \\
\hline & 5803245512 & 9480151470 & 7257039581 & 6984912914 & 7614567030 & 2891601236 & 4 \\
\hline Indicus & ССтTTCTCCG & TGCCTTAAAA & GCCCATCGCT & TTAАТСТСАА & АСTTGCTACC & ACACCGCCCG & C \\
\hline Friesian & $\ldots \ldots \ldots$ & $\ldots \ldots \ldots$ & $\ldots \ldots \ldots$ & $\ldots \ldots \ldots$ & $\ldots \ldots \ldots$ & $\ldots \ldots \ldots$ & . \\
\hline KK 4 & $\ldots \ldots \ldots$ & $\ldots \ldots \ldots$ & $\ldots \ldots \ldots$ & $\ldots \ldots \ldots$ & $\ldots \ldots \ldots$ & $\ldots \ldots \ldots$ & . \\
\hline Taurus & $\ldots$ ССТ $\ldots$ & $\ldots \ldots \ldots$ & $\ldots \ldots$ A. & C..G.... & $\ldots \ldots \ldots$ & $\ldots \ldots \ldots$ & . \\
\hline Limousin & $\ldots$. ССТ.... & $\ldots \ldots \ldots$ & $\ldots \ldots$ A. & C..G..... & $\ldots \ldots \ldots$ & $\ldots \ldots \ldots$ & . \\
\hline Mafriwal & $\ldots$. ССТ... & $\ldots \ldots \ldots$ & \#\#A. & C.G.... & $\ldots \ldots \ldots$ & $\ldots \ldots \ldots$ & . \\
\hline Gaur 1 & $\ldots$ C...C.A & C.TGCC...G & ..T.ССТАAC & C...TC.GG & GTCCAT.CTT & ...TA.T. & $\mathrm{T}$ \\
\hline Gaur 2 & $\ldots$ C... . A & C.TGCC...G & ..T. ССТАAC & C...TC.GG & GTCCAT.CTT & ...TA.T. & $\mathrm{T}$ \\
\hline Gaur 3 & $\ldots$ C...C.A & C.TGCC...G & ..T.ССТАAC & C...TC.GG & GTCCAT.CTT & ...TA.T. & $\mathrm{T}$ \\
\hline Gaur 4 & $\ldots$ C... . A & C.TGCC...G & ..T. ССТАAC & C...TC.GG & GTCCAT.CTT & ...TA.T. & $\mathrm{T}$ \\
\hline Gaur 5 & $\ldots$ C...C.A & C.TGCC...G & ..T. ССТAAC & C....TC.GG & GTCCAT.CTT & ...TA.T. & $\mathrm{T}$ \\
\hline Gaur 6 & $\ldots$ C... . A & C.TGCC...G & ..T. ССТАAC & C...TC.GG & GTCCAT.CTT & ...TA.T. & $\mathrm{T}$ \\
\hline Gaur 7 & .C..С.A & C.TGCC...G & ..Т.ССТAAC & С...TC.GG & GTCCAT.CTT & ...TA.T. & $\mathrm{T}$ \\
\hline Banteng 1 & T....A & CA. GCCG..G & .T.TC.TAA. & C.GGCT... & .TCC..СCT. & ...АTATTTA & $\mathrm{T}$ \\
\hline Banteng 2 & $. \mathrm{T} \ldots . . \mathrm{A}$ & CA. GCCG..G & .T.TC.T.A. & C.G.CT... & . TCC . . CCT & ... AтATTTA & $\mathrm{T}$ \\
\hline Bali 1 & $. T \ldots . A$ & CA.GCCG..G & .T.TC.TAA. & C.G.CT... & . TCC..CCT. & ...АTATTTA & $\mathrm{T}$ \\
\hline Bali 2 & $. \mathrm{T} \ldots . \mathrm{A}$ & CA. GCCG..G & .T.TC.TAA. & C.G.CT... & . TCC . СCT & ...ATATTTA & $\mathrm{T}$ \\
\hline Yak 1 & TTCC..СTTA & .ATA.C.TG. & $\mathrm{A} \ldots \mathrm{C} \cdot \mathrm{AA}$ & .C..T.T.G & . TC . . СTT. & GTC..A.T. & . \\
\hline Yak 3 & TTCC.. СTTA & .ATA.C.TG. & A...C.AA. & .C..T.T.G &. $\mathrm{TC} \ldots \mathrm{TT}$ & GTC..A.T. & . \\
\hline Yak 2 & TTCC..СTTA & .ATA.C.TG. & A...C.AA. & .C..T.T.G & .TC ...TT. & GTC..A.T. & . \\
\hline
\end{tabular}

Position numbers are related to the mitochondrial sequence of the first taxon, "Indicus". Full stops indicate identity to this sequence.

\section{Phylogenetic reconstruction}

\section{Neighbor-joining}

The NJ tree was reconstructed on the basis of Kimura's two-parameter genetic distance. The reliability of the tree topology was assessed by 1000 bootstrap replications (Figure 1). NJ analysis grouped the mitochondrial Cyt $b$ sequences of the subtribe Bovina species into five lineages: zebu cattle, taurine cattle, Malayan gaur, banteng together with Bali cattle, and yak. The tree topology shows that the 20 Bos sequences examined fall into two distinct genetic lineages: 
1) Clade A (consists of B. indicus and B. taurus) and 2) Clade B (consists of Malayan gaur, yak, banteng, and Bali cattle). The Clade B branch is the most basal within the genus Bos, implying that among the five Bos species, Malayan gaur, yak, banteng, and Bali cattle are more "primitive" than zebu and taurine cattle. NJ tree topology reveals the distinction with $100 \%$ bootstrap value for Clade A and a robust bootstrap value of $41 \%$ (data not shown) for Clade B. By using sequences from GenBank as domestic cattle controls, our samples of domestic cattle were categorized into two groups according to respective domestic species of $B$. indicus (Kedah-Kelantan and Friesian) and B. taurus (Mafriwal and Limousin). Significant grouping of species in each independent subclade is readily seen from the clustering of domestic zebu-taurine cattle (100-97\% bootstrap value) and Malaysian gaur-banteng-Bali cattle-yak (100\% bootstrap value). The NJ tree showed that the Malaysian gaur has its own monophyletic clade, separated from other cattle.

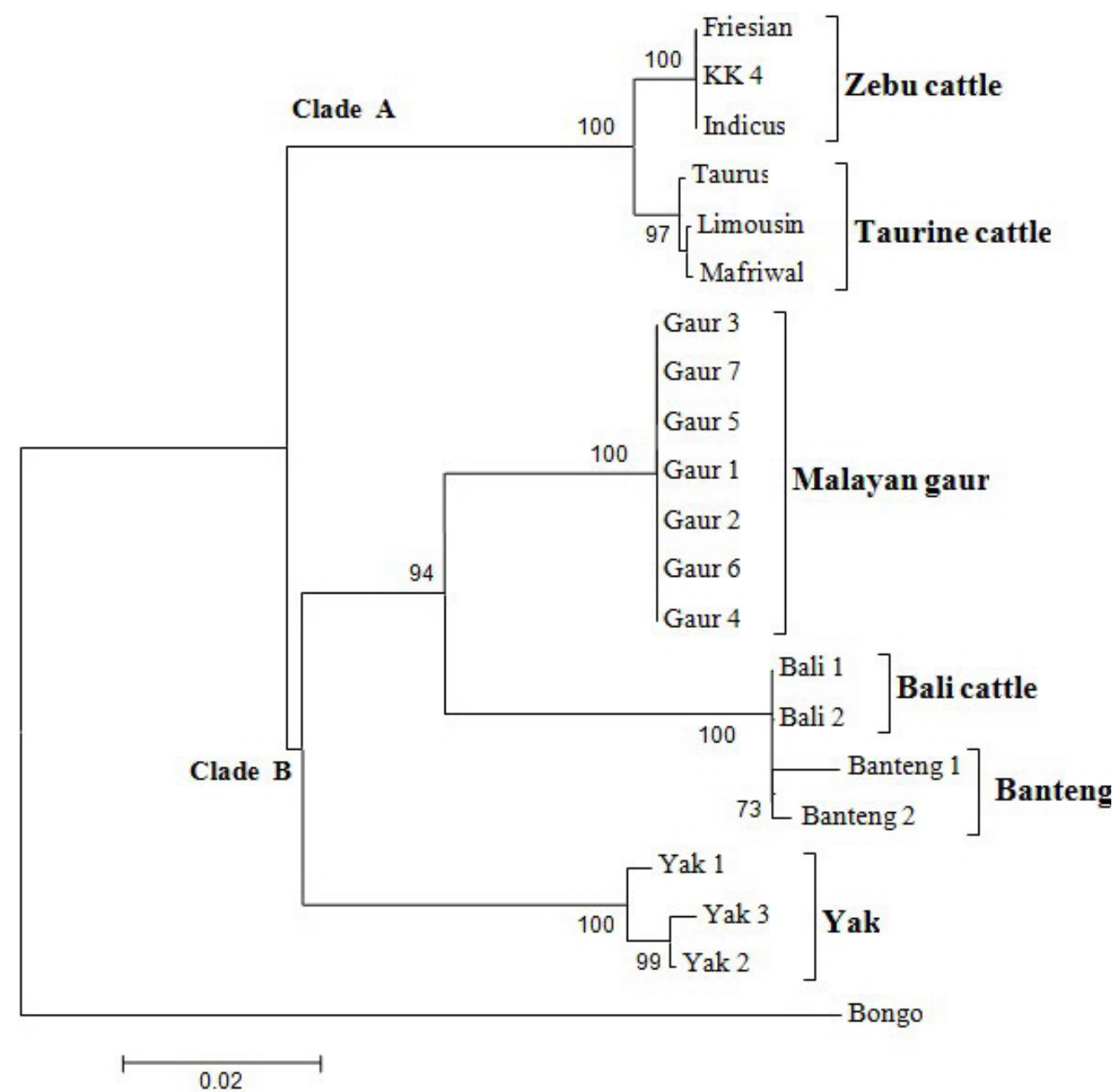

Figure 1. Neighbor-joining tree constructed from 21 sequences (including one outgroup sequence) of the Cyt $b$ gene. The numbers at the branches stand for bootstrap values higher than $70 \%$ of 1000 replications. 


\section{Maximum parsimony}

The MP analysis (branch and bound) based on equally weighted total substitutions produced a tree with 268 steps (Figure 2), with a consistency index of 0.7761 , a homoplasy index of 0.2240 and a retention index of 0.9063 . A bootstrap analysis with 1000 replicates produced a phylogenetic bootstrap tree identical to the tree produced by MP. Essentially, the same topologies produced by NJ and MP revealed monophyly of the genus Bos with respect to the outgroup, the bongo antelope. In general, the cattle group consists of two major classifications, domestic and wild cattle with yak clades. Six domestic cattle samples (zebu and taurine cattle) were clustered together, forming a domestic Clade A with $100 \%$ bootstrap support. Zebu and taurine cattle were further grouped into two independent subclades with high bootstrap values of $99 \%$ (zebu) and $98 \%$ (taurine). For the wild cattle group, the branching together of the Malayan gaur, yak, banteng, and Bali cattle in Clade B is represented by a robust $64 \%$ bootstrap support (data not shown). Based on tree topology, the Malayan gaur forms its own monophyletic clade (100\%), distinct from the banteng and Bali cattle subclade (100\%) and the yak subclade (100\%). Obviously, the Malayan gaur branch has its own authentic matriline origin. The yak clade formed a sister clade of the wild cattle clade, with a high bootstrap value of $100 \%$.

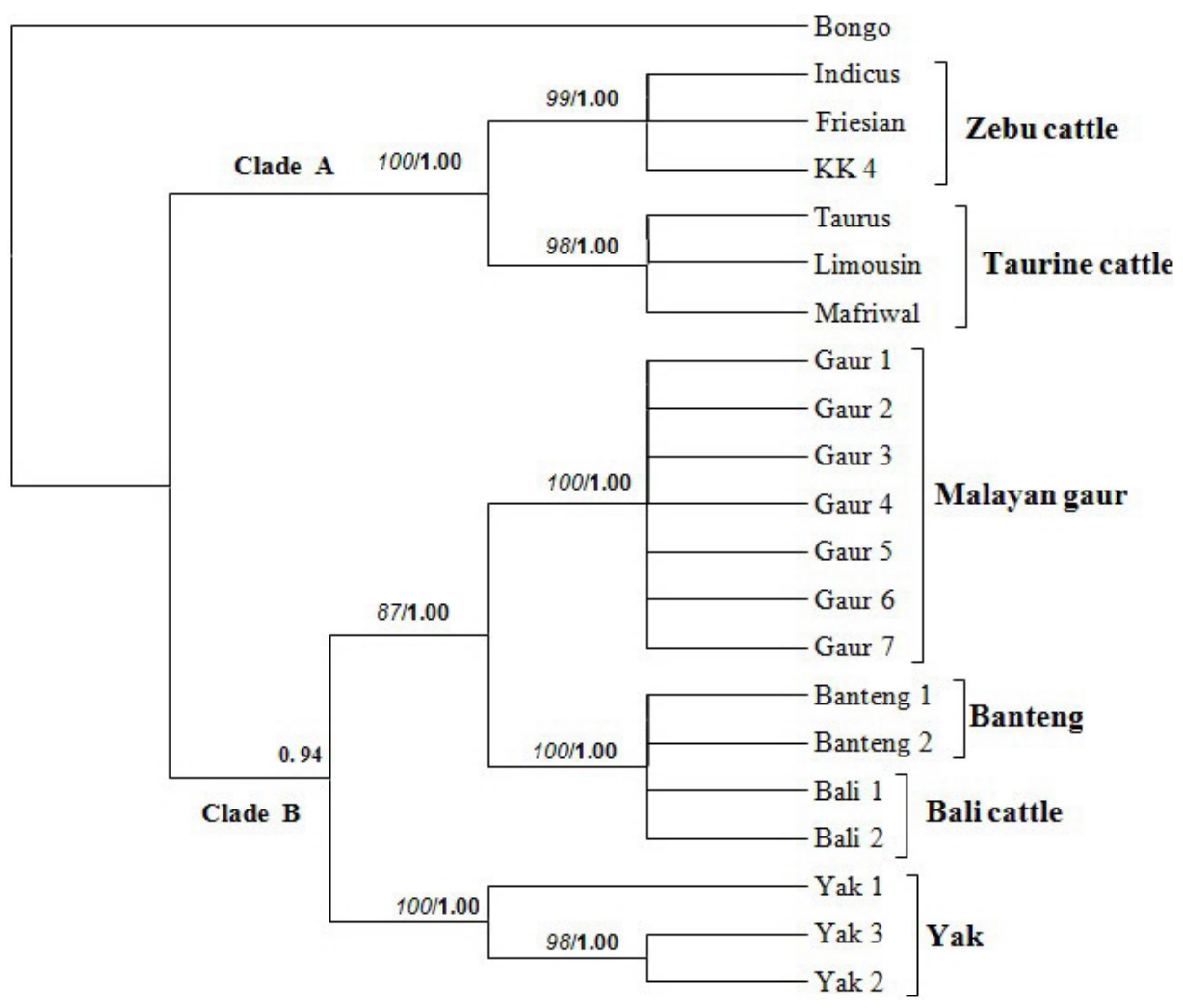

Figure 2. Bootstrap 70\% majority rule consensus maximum parsimony and Bayesian posterior probability tree of 21 cytochrome $b$ gene mtDNA sequences (including one outgroup sequence). Italic numbers at the branches stand for bootstrap values higher than $70 \%$ of 1000 replications and bold numbers stand for Bayesian posterior probability values. 


\section{Bayesian analysis}

Modeltest 3.7 was used to derive the best model with best fit estimates of base pair frequencies, proportion of invariant sites and the gamma shape parameter. For the Cyt $b$ sequences, the best model computed for Bayesian analysis was TVM $+\mathrm{G}$, with a proportion of invariable sites of 0 and a gamma distribution shape parameter of 0.1092 . Bayesian inference using the TVM $+\mathrm{G}$ substitution model in MrBayes was made by running two simultaneous metropolis-coupled Monte-Carlo Markov chains for 1,000,000 generations, with 0.002793 split frequencies probability (P). A tree was sampled for every 100 generations and a consensus topology tree of 9001 trees was generated by omitting the first 1000 trees of 10,000 (burning).

Bayesian analysis produced essentially the same topology as the previous analyses (MP and $\mathrm{NJ}$ ) and revealed a monophyly of the Malayan gaur with a Bayesian posterior probability of 100\% (1.00) (Figure 2). The Bayesian posterior probability values for each of the branches shared relatively high values of 1.00 except for the basal branch of the Clade B, which had a 0.94 Bayesian posterior probability value. This Bayesian posterior probability value pattern supports the clustering of each assigned species as a strong group, except for the grouping of yak and wild cattle in major Clade B (unresolved). According to Leache and Reeder (2002), only a posterior probability of $95 \%(0.95)$ or greater should be considered significant (resolved).

\section{Genetic distance}

An examination of the pairwise genetic distance within the four cattle species was carried out based on Kimura's two-parameter test in PAUP. Table 4 shows the genetic distance percentages between the Malayan gaur and other species of the Bos genus. Banteng and Bali cattle were found to be the closest species to the Malayan gaur. Both domestic zebu and taurine cattle had greater genetic distances from gaur. Genetic distances between banteng and Bali cattle compared with the other two domestic groups were quite similar to the distances between the Malayan gaur and the other two species. Zebu and taurine cattle had a shorter genetic distance from each other. Yak showed no significant distance differences between itself and every species of Bos. This genetic distance value supports the separate classification of wild (gaur and banteng) and domestic cattle (zebu and taurine cattle) as well as the separation of cattle groups (gaur, banteng, zebu, taurine, and Bali cattle) from other Bos species, yak. The Bos genus was also found to have large genetic distances from the bongo antelope.

\begin{tabular}{|c|c|c|c|c|c|c|}
\hline Species & Banteng & Bali cattle & Zebu cattle & Taurine cattle & Yak & Bongo \\
\hline Gaur & 5.86 & 5.45 & 8.01 & 7.97 & 7.18 & 14.71 \\
\hline Banteng & - & 0.43 & 8.63 & 8.63 & 8.88 & 16.59 \\
\hline Bali cattle & - & - & 8.26 & 8.21 & 8.92 & 16.02 \\
\hline Zebu cattle & - & - & - & 1.17 & 7.92 & 15.26 \\
\hline Taurine cattle & - & - & - & - & 7.80 & 14.93 \\
\hline Yak & - & - & - & - & - & 14.99 \\
\hline
\end{tabular}

\section{DISCUSSION}

Data from the Cyt $b$ gene shows a concurrent pattern of genetic distances, which in- 
dicates significant genetic divergence between B. g. hubbacki and other Bos species. Tree topologies from different phylogenetic analyses clearly indicated that Malayan gaur forms its own distinct monophyletic clade. As expected, Malayan gaur grouped together with banteng. These topologies were strongly supported by significance values of Cyt $b$ genetic distances, with banteng and Bali cattle as the closest descendants. This was true for classification assigned for both gaur and banteng species as wild cattle, with earlier divergence time than other cattle species based on tree topologies. In earlier reports, B. gaurus was grouped with B. javanicus (banteng) in the wild cattle clade (Schreiber et al., 1999; Lai et al., 2006; Stock et al., 2009). This arrangement was also confirmed by research using autosomal genes (MacEachern et al., 2009). Our molecular data have further corroborated this taxonomic distinction. Tree topologies showed that yak is a subclade of the major clade that consists of the wild cattle subclade (Malayan gaur and banteng). However, this grouping in tree topologies was not fully resolved with robust bootstrap and Bayesian posterior probability values. Phylogenetically, yak has been grouped with American bison in the same clade, as two independent species (Verkaar et al., 2004). At a higher lineage level, Verkaar et al. (2004) found that the yak and American bison were associated with a subclade in a major clade together with the subclade of gaur and banteng. Our results showed concurrent patterns for the placement of yak in the same major clade with wild cattle. On the other hand, the close relationship of Malayan gaur and local gayal (B. frontalis) or selembu still cannot be determined. This is due to the lack of samples for phylogenetic analyses. However, earlier report findings stated that there are three systematic deposition possibilities of this hybrid form of gaur: a) gayal will be deposited in an independent clade that has a close relationship with gaur (Verkaar et al., 2004); b) gayal will be deposited in a clade together with gaur (Ma et al., 2007), and/or c) gayal will be deposited in a clade with either zebu or taurine cattle (Li et al., 2008).

Among domestic cattle, B. indicus and B. taurus claded together in a group with distinct separation from each other. Genetic distance and relatively high values of bootstrapping and Bayesian posterior probability supported the distinction of these two domestic species. These findings are identical to some earlier reports based on sequences of mtDNA of cattle species (Hassanin and Ropiquet, 2004; Verkaar et al., 2004; Hassanin et al., 2006; Ma et al., 2007). Bradley et al. (1996) concluded that the association of taurine and zebu cattle reflects the fertility of female as well male hybrid offspring, with a divergence time of 100,000 to 200,000 years. Through a domestication event that occurred 8000-10,000 years ago, both species are believed to be originated from the aurochs, B. primigenius (Epstein, 1971; MacHugh et al., 1997). However, there appears to be an insertion of domestic Bali cattle in the banteng subclade within the wild cattle group instead of in the domestic cattle group. According to Mohamad et al. (2009), Bali cattle are the domestic type of banteng in which domestication took place around 3500 years BC. It is currently the main representative of the domestic banteng. It is kept on several Indonesian islands and also in other countries. This explains the matrilineage genetic inheritance of mtDNA of banteng in Bali cattle. Theoretically, the mtDNA of banteng was transferred into the Bali cattle ancestor through mating between a zebu/taurine male and a banteng female during historic times. Therefore, the grouping of Bali cattle and banteng seems to make sense. Similarly, the molecular phylogeny obtained here is nearly concordant with the morphological phylogeny of domestic cattle, the humpless taurine and the humped zebu, except for Bali cattle.

This study demonstrates the potential application of mitochondrial markers in understanding the relationship among various Bos species. Since mtDNA is a haploid molecule and maternally inherited, it has one-fourth the effective population size $(\mathrm{Ne})$ of nuclear genes 
(Wilson et al., 1985). This makes mtDNA more sensitive than nuclear genes to demographic processes such as population fragmentation and bottleneck (Dadi et al., 2009). In our study, the Cyt $b$ gene employed appears to be an independent indicator of the phylogenetic relationships among the Bos species. Investigation on variability of parsimony informative characters in this study showed that the Cyt $b$ gene is conserved and suitable to be used as a tool for identifying the relationship of Bos species. On the other hand, the length of some mtDNA regions used is also important in order to obtain better resolved phylogenetic results, as with the full-length Cyt $b$ fragments used in our study.

The independent classification of Malayan gaur increases the relevance of conservation efforts, especially considering its decreased population number in the wild. Any translocation, reintroducing or breeding in captivity program should consider the best plan ecologically and genetically, to help maintain this native Malaysian subspecies. Studies of genetic diversity, including phylogeography, are essential in order to have a better understanding of the relationship among Malayan gaur individuals with the other two subspecies of gaurs. These goals can be achieved with the help of rapidly evolving mtDNA regions such as cytochrome $\mathrm{c}$ oxidase I (COI) and control region (D-Loop), which have been extensively used for resolving genetic uncertainties outside the Bovini tribe (Lim et al., 2010). Further research with a larger sample size and different molecular markers (i.e., Y-chromosomes and microsatellites) could provide alternative views on phylogenetic relationships of Bos species.

\section{ACKNOWLEDGMENTS}

We would like to express our sincere appreciation to the Faculty of Science and Technology, UKM. We also thank the Agro-Biotechnology Institute (ABI), MOSTI, especially Dr. Fazly Ann Zainalabidin and Siti Romaino Mohd. Nor. Our special thanks to the Department of Wildlife and National Parks (PERHILITAN), especially the Director General, Director Ex-situ Conservation Division (Saharudin Anan) and Jeffrine Rovie Ryan Japning and the National Institute of Veterinary Biodiversity (IBVK) for providing genetic samples. This study was funded by research grant (\#STGL-003-2009 and \#08-05-ABI-AB032/1) received from the Agro-Biotechnology Institute (ABI), MOSTI and UKM-OUP-FST-2010. We also express our gratitude to all who were involved either directly or indirectly in this study.

\section{REFERENCES}

Bradley DG, MacHugh DE, Cunningham P and Loftus RT (1996). Mitochondrial diversity and the origins of African and European cattle. Proc. Natl. Acad. Sci. U. S. A. 93: 5131-5135.

Brennan EJ (1995). Genetics and Conservation of Gaur and Asian Elephants on the Malaysia Peninsula. Doctoral thesis, Universiti Malaysia Sarawak, Knoxville.

Buntjer JB, Otsen M, Nijman IJ, Kuiper MT, et al. (2002). Phylogeny of bovine species based on AFLP fingerprinting. Heredity 88: 46-51.

Cai X, Chen H, Lei C, Wang S, et al. (2007). mtDNA diversity and genetic lineages of eighteen cattle breeds from Bos taurus and Bos indicus in China. Genetica 131: 175-183.

Conry P (1989). Gaur Bos gaurus and development in Malaysia. Biol. Conservat. 49: 47-65.

Dadi H, Tibbo M, Takahashi Y, Nomura K, et al. (2009). Variation in mitochondrial DNA and maternal genetic ancestry of Ethiopian cattle populations. Anim. Genet. 40: 556-559.

Duckworth JW, Steinmetz R, Timmins RJ, Anak P et al. (2008). Bos gaurus. In: IUCN2010. IUCN Red List of Threatened Species. Version 2010.2. Available at [www.iucnredlist.org]. Accessed July 14, 2010.

Epstein H (1971). The Origin of the Domestic Animals of Africa. 1st edn. African Publishing Corporation, New York. 
Ginja C, Penedo MC, Melucci L, Quiroz J, et al. (2010). Origins and genetic diversity of New World Creole cattle: inferences from mitochondrial and Y-chromosome polymorphisms. Anim. Genet. 41: 128-141.

Groves C (2003). Taxonomy of ungulates of the Indian Subcontinent. J. Bombay Nat. Hist. Soc. 100: 341-361.

Gu Z, Zhao X, Li N and Wu C (2007). Complete sequence of the yak (Bos grunniens) mitochondrial genome and its evolutionary relationship with other ruminants. Mol. Phylogenet. Evol. 42: 248-255.

Hassanin A and Ropiquet A (2004). Molecular phylogeny of the tribe Bovini (Bovidae, Bovinae) and the taxonomic status of the Kouprey, Bos sauveli Urbain 1937. Mol. Phylogenet. Evol. 33: 896-907.

Hassanin A, Ropiquet A, Cornette R, Tranier M, et al. (2006). Has the kouprey (Bos sauveli Urbain, 1937) been domesticated in Cambodia? C. R. Biol. 329: 124-135.

Irwin DM, Kocher TD and Wilson AC (1991). Evolution of the cytochrome b gene of mammals. J. Mol. Evol. 32: 128-144.

Kikkawa Y, Takada T, Sutopo, Nomura K, et al. (2003). Phylogenies using mtDNA and SRY provide evidence for malemediated introgression in Asian domestic cattle. Anim. Genet. 34: 96-101.

Lai SJ, Liu YP, Liu YX, Li XW, et al. (2006). Genetic diversity and origin of Chinese cattle revealed by mtDNA D-loop sequence variation. Mol. Phylogenet. Evol. 38: 146-154.

Leache AD and Reeder TW (2002). Molecular systematics of the eastern fence lizard (Sceloporus undulatus): a comparison of parsimony, likelihood, and Bayesian approaches. Syst. Biol. 51: 44-68.

Li SP, Chang H, Ma GL and Cheng HY (2008). Molecular phylogeny of the gayal in Yunnan China inferred from the analysis of cytochrome b gene entire sequences. Asian Austral. J. Anim. 21: 789-793.

Lim LS, Ang KC, Mahani MC, Shahrom AW, et al. (2010). Mitochondrial DNA polymorphism and phylogenetic relationships of Proto Malays in Peninsular Malaysia. J. Biol. Sci. 10: 71-83.

Ma G, Chang H, Li S, Chen H, et al. (2007). Phylogenetic relationships and status quo of colonies for gayal based on analysis of cytochrome B gene partial sequences. J. Genet. Genomics 34: 413-419.

MacEachern S, McEwan J and Goddard M (2009). Phylogenetic reconstruction and the identification of ancient polymorphism in the Bovini tribe (Bovidae, Bovinae). BMC Genomics 10: 177.

MacHugh DE, Shriver MD, Loftus RT, Cunningham P, et al. (1997). Microsatellite DNA variation and the evolution, domestication and phylogeography of taurine and zebu cattle (Bos taurus and Bos indicus). Genetics 146: 1071-1086.

Matthee CA and Davis SK (2001). Molecular insights into the evolution of the family Bovidae: a nuclear DNA perspective. Mol. Biol. Evol. 18: 1220-1230.

Md-Zain BM, Morales JC, Hassan MN, Abdul J, et al. (2008). Is Presbytis a distinct monophyletic genus: inferences from mitochondrial DNA sequences. Asian Primates J. 1: 26-36.

Md-Zain BM, Lee SJ, Lakim M, Ampeng A, et al. (2010a). Phylogenetic position of Tarsius bancanus based on partial cytochrome b DNA sequences. J. Biol. Sci. 10: 348-354.

Md-Zain BM, Mohamad M, Ernie-Muneerah MA, Ampeng A, et al. (2010b). Phylogenetic relationships of Malaysian monkeys, Cercopithecidae, based on mitochondrial cytochrome c sequences. Genet. Mol. Res. 9: 1987-1996.

Medway L (1983). Wild Mammals of Malaya (Peninsular Malaysia) and Singapore. 2nd edn. Oxford University Press, Kuala Lumpur.

Mohamad K, Olsson M, van Tol HT, Mikko S, et al. (2009). On the origin of Indonesian cattle. PLoS One 4: e5490.

Nguyen MH (2009). The status of vulnerable gaur Bos gaurus and endangered banteng Bos javanicus in Ea So Nature Reserve and Yok Don and Cat Tien National Parks, Vietnam. Oryx 43: 129-135.

Nguyen TT, Genini S, Bui LC, Voegeli P, et al. (2007). Genomic conservation of cattle microsatellite loci in wild gaur (Bos gaurus) and current genetic status of this species in Vietnam. BMC Genet. 8: 77.

Pevsner J (2009). Bioinformatics and Functional Genomics. 2nd edn. Wiley-Blackwell, Hoboken.

Posada D and Crandall KA (1998). MODELTEST: testing the model of DNA substitution. Bioinformatics 14: 817-818.

Rivière-Dobigny T, Doan LP, Quang NL, Maillard JC, et al. (2009). Species identification, molecular sexing and genotyping using non-invasive approaches in two wild bovids species: Bos gaurus and Bos javanicus. Zoo. Biol. 28: 127-136.

Sahir O (2001). Breeding performance on the Malaysian captive gaur. J. Wildl. Parks 19: 25-32.

Schreiber A, Seibold I, Notzold G and Wink M (1999). Cytochrome $b$ gene haplotypes characterize chromosomal lineages of anoa, the Sulawesi dwarf buffalo (Bovidae: Bubalus sp.). J. Hered. 90: 165-176.

Simonelli P, Troedsson C, Nejstgaard J, Zech K, et al. (2009). Evaluation of DNA extraction and handling procedures for PCR-based copepod feeding studies. J. Plankton Res. 31: 1465-1474.

Stock F, Edwards CJ, Bollongino R, Finlay EK, et al. (2009). Cytochrome $b$ sequences of ancient cattle and wild ox support phylogenetic complexity in the ancient and modern bovine populations. Anim. Genet. 40: 694-700.

Swofford DL (2002). Phylogenetic Analysis Using Parsimony (and Other Methods). Version 4.0 Beta. Sinauer Associates, Sunderland.

Vasil'ev VA, Steklenev EP, Morozova EV and Semenova SK (2002). DNA fingerprinting of individual species and intergeneric and interspecific hybrids of genera Bos and Bison, subfamily Bovinae. Genetika 38: 515-520. 
Verkaar EL, Nijman IJ, Beeke M, Hanekamp E, et al. (2004). Maternal and paternal lineages in cross-breeding bovine species. Has wisent a hybrid origin? Mol. Biol. Evol. 21: 1165-1170.

Wilson AC, Cann RL, Carr SM, George M, et al. (1985). Mitochondrial DNA and two perspectives on evolutionary genetics. Biol. J. Linn. Soc. 26: 375-400.

Wilson DE and Reeder DAM (2005). Mammal Species of the World. A Taxonomic and Geographic Reference. 3rd edn. Johns Hopkins University Press, Baltimore.

Yusof E (1981). Seladang (Bos gaurus hubbacki) in Malaysia. Unpublished Report by the Department of Wildlife and National Parks, Peninsular Malaysia. 